\title{
Die Septuaginta - Orte und Intentionen
}

\author{
5. Internationale Fachtagung veranstaltet von Septuaginta Deutsch (LXX.D), \\ Wuppertal 24.-27. Juli 2014 \\ Hrsg. v. Siegfried Kreuzer, Martin Meiser u. Marcus Sigismund, in Verb. m. Martin \\ Karrer u. Wolfgang Kraus
}

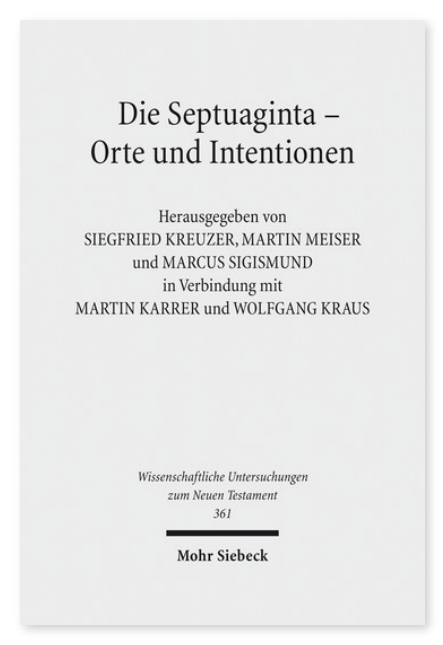

2016. XVI, 923 Seiten. WUNT I 361

ISBN 978-3-16-154724-9

DOI 10.1628/978-3-16-154724-9

eBook PDF $249,00 €$

ISBN 978-3-16-153832-2

Leinen $249,00 €$
Die Septuaginta ist als jüdische Bibelübersetzung ab dem 3. Jahrhundert v.Chr. entstanden und wurde zur zentralen Grundlage des Judentums in der griechisch-sprachigen Welt. Textgeschichtlich ist sie für das Alte Testament die wichtigste Quelle neben dem hebräisch-masoretischen Text und den nur sehr unvollständig erhaltenen biblischen Texten aus Qumran. Zudem gibt sie Einblick in die Theologie und das Schriftverständnis des antiken Judentums. Neutestamentliche Autoren zitieren das Alte Testament häufig in Gestalt der Septuaginta; in den orthodoxen Kirchen gilt sie bis heute als offizieller Text des Alten Testaments.

Die Septuaginta-Forschung bildet einen eigenständigen Bereich, der im Schnittfeld steht mit antiker Judaistik und den historisch-exegetisch orientierten Wissenschaften innerhalb der Theologie. Der vorliegende Band ist erwachsen aus der 5. Internationalen Tagung des Projektes Septuaginta Deutsch im Juli 2014 in Wuppertal.

\section{Inhaltsübersicht}

\section{Orte}

\section{Kontexte und Orte der Entstehung und Rezeption}

Martin Karrer: Septuaginta und antike Philosophie - Knut Usener: Plutarch und das Judentum - Plutarch und die Septuaginta? - Johann Cook: The Provenience of the Septuagint: A Case Study of LXX Proverbs; LXX Job and 4 Maccabees Michael Lattke: Die Psalmen Salomos: Orte und Intentionen - Marcus Sigismund: Die ägyptische Rezension des JosuaLXX im Lichte der sahidischen Überlieferung - Bonifatia Gesche: Von Nordafrika über Paris nach Stuttgart: Wie kommt die verderbte Fassung der Übersetzung von Esdras A' in die Vulgata? - Siegfried Kreuzer: Zum textgeschichtlichen Ort der Dodekapropheton-Zitate im Neuen Testament

\section{Reale und literarische Welten}

Gert Jacobus Steyn: Heliopolis and On in the Septuagint - James K. Aitken: Moses's Өíßıৎ - Michaël N. van der Meer: Galilee in the Septuagint. Textual Criticism and Topography in Joshua 19:10-39 - Frank Ueberschaer: Die Welt des Ben Sira. Orte und Räume im Denken Ben Siras - Martin Rösel: Die himmlische Welt der Septuaginta. Angelologische Akzentuierungen am Beispiel des Danielbuches - Jutta Leonhardt-Balzer: Philo and the Garden of Eden: An Exegete, his Text and his Tools - Martin Meiser: Der Traum in der griechisch-römischen Antike, im antiken Judentum und im antiken Christentum

\section{Textkritik und Textgeschichte}

Emanuel Tov: The Shared Tradition of the Septuagint and the Samaritan Pentateuch - Innocent Himbaza: What are the consequences if 4QLXXLeva contains earliest formulation of the Septuagint? - Tuukka Kauhanen: Septuagint in the West. The Significance of the Post-Lucianic Latin Witnesses for the Textual History of Kings - Adrian Schenker: Archetype and Late Literary Developments in 2 Kings 1:17-18 and 8:16. Recensions in the Masoretic Text and in the Old Greek - Felix Albrecht: Die alexandrinische Überlieferung und die Rezension des Hesych von Alexandrien in den Prophetenbüchern der Septuaginta Claudine Cavallier: Esther 1, 13-20: problèmes textuels - Robert V.J. Hiebert: A New Critical Edition of Greek IV Maccabees Michael Segal: The Old Greek Version and Masoretic Text of Daniel 6 - Wolfgang Schütte: Die Exegese der griechischen Textgraphik und der Codex Venetus - Stefan Mulder: 'A conquering of animals': Symmachus' depoliticising translation reexamined

\section{Intentionen}

Philologie

Theo A.W. van der Louw: Did the LXX Translators Really Intend the Greek Text as it is? - Takamitsu Muraoka: Septuagint Greek:

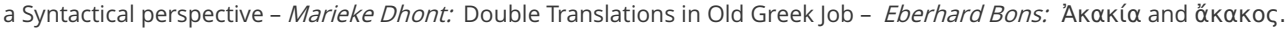
Considerations on a Septuagint term for »innocence« - Christoph Kugelmeier: Zu einer besonderen Bedeutung der aus ả $\rho \varepsilon-$ abgeleiteten Wortgruppe - Hong-Joon Kim: Zur Relevanz der Wiedergabe von צדקה mit ع̌ $\lambda \varepsilon$ ع

\section{Theologie}

Martina Kepper: Kontextualisierende Übersetzungspraxis in der Genesis-Septuaginta? - William Loader: Attitudes towards Sexuality in the LXX Translations of Contentious Texts - Larry Perkins: Israel's Military Characterization in Greek Exodus Ralph Brucker: Zum 'Sitz im Leben' des Septuaginta-Psalters - Annette Weißenrieder: Body Discourse in Job: Translation of

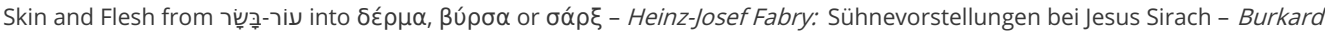
M. Zapff: Schriftgelehrte Rezeptionen im hebräischen, griechischen und syrischen Sirach - Cécile Dogniez: Volonté et motif: les intentions du traducteur des Douze Petits Prophètes - Daniela Scialabba: The LXX translation of Jonah 1:6. Text-critical and exegetical considerations - Arie van der Kooij: »Do you understand what you are reading (Acts 8:30). On Septuagint Hermeneutics and the Book of Isaiah - Jelle Verburg: Harmonisation in Isaiah 35 - Johanna Erzberger: Nebuchadnezzar, Lord of the Wild Animals: Understanding a Difference Between JerLXX and JerMT in Light of Dan - Jan Joosten: The Origin of the Septuagint Canon

Rezeption

Barbara Schmitz: »... using different names, as Zeus and Dis« (Arist 16). Concepts of »God« in the Letter of Aristeas - Mogens 
Müller: Motive der Septuaginta bei Aristobul und ihre Intention - Wolfgang Kraus: Zur Frage der Ursprünglichkeit und Rezeption von Bar 3,38 - Jonathan Draper: The Old Testament in the Didache and in Subsequent Church Orders - Silke Diederich: Leiden und Loben. Zur Psalmenrezeption in Dracontius De laudibus Deei - Stefan Freund: Die Psalmen als übersetzte Dichtung in der Wahrnehmung des Hilarius von Poitiers - Meike Rühl: Pia festa litterarum. Eine Fallstudie zur christlichen Transformation römischer Conviviallyrik - Christoph Schubert: Poetische Transformationen: Commodian und der Psalter - Egert Pöhlmann: Der Trinitarische Hymnus (POXY 1786) und sein Umfeld

Siegfried Kreuzer Geboren 1949; Promotion und Habilitation in Ev. Theologie; 1991-2015 Professor für Altes Testament an der Kirchlichen Hochschule in Wuppertal; seit 1999 Mitwirkung bei Septuaginta Deutsch und am Institut für Septuaginta und Biblische Textforschung.

Martin Meiser Born 1957; 1983-91 Lutheran minister in Bavaria; 1991-2001 Assistant for New Testament in Erlangen; 2001 05 Assistant for Early Church History in Mainz; 2005-07 Vicarious Professor in Münster/Westphalia; since 2007 Associate Professor in Saarbrücken.

Marcus Sigismund Geboren 1971; 2002 Dr. phil.; seit 1999 Lehrbeauftragter an der Bergischen Universität Wuppertal; seit 2007 Wissenschaftlicher Mitarbeiter am Institut für Septuaginta und biblische Textforschung, seit 2022 Koordinator der UniService Digitalisierung der Lehre an der Bergischen Universität Wuppertal.

https://orcid.org/0000-0002-9345-767X

Martin Karrer ist Professor für Neues Testament an der Kirchlichen Hochschule Wuppertal.

Wolfgang Kraus Born 1955; 1990 doctorate; 1994 Habilitation; Professor emeritus for New Testament Studies at the University of the Saarland, Saarbruecken.

Jetzt bestellen:

https://mohrsiebeck.com/buch/die-septuaginta-orte-und-intentionen-9783161547249?no_cache=1

order@mohrsiebeck.com

Telefon: $+49(0) 7071-923-17$

Telefax: $+49(0) 7071-51104$ 